\title{
Regenerative Endodontics Overview - A New Emerging Trend in Dentistry
}

\author{
Kapil Jhajharia* \\ Department of Conservative Dentistry and Endodontics, Faculty of Dentistry, Melaka Manipal Medical College, Melaka, Malaysia
}

*Corresponding author: Kapil Jhajharia, Department of Conservative Dentistry and Endodontics, Faculty of Dentistry, Melaka Manipal Medical College, Melaka, Malaysia, Tel: 006067989 200; E-mail: kapilbds@gmail.com

Received date: February 16, 2018; Accepted date: February 19, 2018; Published date: February 21, 2018

Copyright: (C) 2018 Jhajharia K. This is an open-access article distributed under the terms of the creative Commons Attribution License, which permits unrestricted use, distribution and reproduction in any medium, provided the original author and source are credited.

Citation: Jhajharia K. Regenerative Endodontics Overview - A New Emerging Trend in Dentistry. Periodon Prosthodon. 2018, Vol.4 No.1:03.

\section{Editorial}

The aim of contemporary restorative dentistry is to restore tooth functionally as well as cosmetically. The natural tooth structure such as enamel, dentin and cementum have little regenerative ability [1]. Recently, many new materials developed to restore these damaged tooth structures. Since these materials have proved some effectiveness in restoring these tooth structures but the mechanical and physical properties of these material is not same as those of tooth structures. That's why, replacing the tooth tissue is the only option. Millions of diseases or damaged teeth are saved by root canal therapy. However, ideal is to use a regenerative approach is to remove damaged pulp tissue and replace with healthy pulp tissue for revitalization of tooth. Many of these new and advanced emerging techniques from regenerative medicine can be adopted in endodontics speciality to develop endodontic procedures and improve patient care overall.

Nowadays, a new and exciting domain of research is tissue engineering with its dental implications [2].

Regenerative endodontics is the new emerging trend in dentistry which is growing tremendously with each passing year. Basically, these procedures are different treatments which are biologically based with use of pulpal cells to replace diseased portions of the dental pulp or to allow complete formation of a dental pulp-like tissue that will act as the original dental pulp [3].

Today, main concern in regenerative endodontics is to use different types of stem cells on the scaffold in diseased root canal system of tooth. Lots of information is present in regenerative studies till now, but still more is needed to know about the interactions which occur between all kinds of cells and their differentiation and proliferation, different groups of growth factors and different materials used to develop a wellformed, functioning tooth. Regenerative endodontics is a very vast subject that deals with various aspects to create and deliver different tissues with use of tissue engineering therapy so that a missing or diseased pulp can be replaced. It consists of use of growth factors either externally or internally from dentin or remained pulp, scaffold, vascular supply, growth factors, signalling mechanisms, migration and differentiation of cells to form pulp like tissue [4].
It is possible with these tissue engineering techniques to repair damaged organ or create replacement organ. It could help to achieve regeneration of enamel and dentin to restore damaged or lost tooth structures in future. There are different possible ways to regenerate dentin and pulp with biologically based novel approaches $[5,6]$. Various areas of research that might have application in the development of regenerative endodontic techniques are Root canal revascularization via blood clotting, Postnatal stem cell therapy, Pulp implantation, Scaffold implantation, Injectable scaffold delivery, Three Dimensional cell printing, Gene therapy and Cell therapy [1].

The main aim of regenerative endodontics is to understand all possible processes and mechanisms for restoring a healthy and vital tissues within a tooth in situ [7].

\section{Conclusion}

The purpose of this review is to give an insight on current and valuable role of tissue engineering as a new approach in endodontics to improve treatment outcome for patients in dentistry.

\section{References}

1. Murray PE, Garcia-Godoy F, Hargreaves KM (2007) Regenerative endodontics: a review of current status and a call for action. J Endod 33: 377-390.

2. Harold EG (2012) Regenerative Endodontics and Tissue Engineering What the Future Holds. Dent Clin N Am 56: 677-689.

3. Bose R, Nummikoski P, Hargreaves K (2009) A retrospective evaluation of radiographic root canal systems treated with regenerative endodontic procedures. J Endod 35: 1343-1349.

4. Kadar K, Kiraly M, Porcsalmy B (2009) Differentiation potential of stem cells from human dental origin-promise of tissue engineering. J Physiol Pharmacol 60 (Suppl 7): 167-175.

5. Murray PE, About I, Lumley P, Franquin JC, Windsor LJ, et al. (2003) Odontoblast morphology and dental repair. J Dent 31: 75-82.

6. About I, Mitsiadis TA (2011) Molecular aspect of tooth pathogenesis and repair: in vivo and in vitro models. Adv Dent Res 15: 59-62. 
7. Galler KM, D'Souza RN (2011) Tissue engineering approaches for regenerative dentistry. Regen Med 6: 111-124. 